NBER WORKING PAPER SERIES

\title{
CHANGING ECONOMIC GEOGRAPHY
} AND VERTICAL LINKAGES IN JAPAN

Eiichi Tomiura

Working Paper 9899

http://www.nber.org/papers/w9899

\author{
NATIONAL BUREAU OF ECONOMIC RESEARCH \\ 1050 Massachusetts Avenue \\ Cambridge, MA 02138 \\ August 2003
}

This paper was originally presented as "Changing economic geography and import penetration in Japan" at NBER-CEPR-TECR-RIETI $15^{\text {th }}$ Annual Trio International Conference, and will appear in Journal of the Japanese and International Economies, forthcoming. I deeply appreciate valuable comments from conference participants, especially Peter Debaere, Kyoji Fukao, Takeo Hoshi, Fukunari Kimura, Sadao Nagaoka, Stephen Redding, John Ries, and David Weinstein. All remaining errors are mine. The financial support by the Grant-in-Aid for Scientific Research No. 13630056 from Ministry of Education and Science is acknowledged. The views expressed herein are those of the authors and not necessarily those of the National Bureau of Economic Research.

C2003 by Eiichi Tomiura. All rights reserved. Short sections of text, not to exceed two paragraphs, may be quoted without explicit permission provided that full credit, including $\mathbb{C}$ notice, is given to the source. 
Changing Economic Geography and Vertical Linkages in Japan

Eiichi Tomiura

NBER Working Paper No. 9899

August 2003

JEL No. R12, R34, F14, J23

\begin{abstract}
In Japan, the manufacturing has become geographically dispersed in the 1990s, when the import share has risen after the historic exchange rate appreciation. As is consistent with the interpretation that import penetration undermines regional input-output linkages, our regressions detect the significant decline of industrial concentrations previously established near output absorbers, especially in industries with high import share growths. This paper also finds that local knowledge spillovers and immobile specialized labor affect regional growth. Thus, while regional demand of tradable outputs matters less, regional supply of inputs, especially non-tradable inputs, remains critical for manufacturing locations.
\end{abstract}

\author{
Eiichi Tomiura \\ Research Institute for Economics and Business Administration \\ Kobe University and TCER \\ 2-1 Rokko-dai, Nada-ku, Kobe City 657-8501, Japan \\ tomiura@rieb.kobe-u.ac.jp
}




\section{INTRODUCTION}

The import share has risen in many countries, as barriers to border-crossing transactions have substantially been removed. The geographical distribution of industries within a country is likely to be affected by increased flows of foreign goods because import penetration tends to undermine input-output linkages among domestic industries. In the last decade, the industrial location has become more dispersed across regions in Japan after the historic yen appreciation. Therefore, this paper examines Japan's changing economic geography, focusing on vertical linkages.

The effects of international trade on internal geography have been theoretically explored, but empirical investigations have been limited. Fujita, Krugman and Venables (1999) construct an insightful model, of which the testable implication includes that the employment growth must be lower after trade liberalization in the regions where input-output linkages among regional industries were previously stronger. ${ }^{1}$ This paper is inspired by the econometric specification by Hanson (1998) on the case of Mexico, where industries dispersed from the concentration in Mexico City under the drastic trade liberalization.

The purpose of this paper is threefold. First, this paper empirically investigates the relationship between internal geography and international trade, focusing on the role of inter-industry linkages. The effect of regional industrial composition, rather than general urban agglomeration, is emphasized, since import penetration affects internal geography by weakening input-output linkages among regional industries. Forward and backward linkages are distinguished since the cross-regional tradability of intermediate inputs tends to be noticeably lower than that of

1 By explicitly incorporating inter-industry linkages, the models developed in Fujita, Krugman, and Venables (1999) extend the one-sector model by Krugman and Livas-Elizondo (1996), which focuses on the effect of consumers on giant metropolis. Both of these models are in the abstract framework of two-region country, but the testable implications empirically survive for multi-region settings in the real world. 
final products. ${ }^{2}$ By combining Census of Manufacturers data with Input-Output Table data, this paper constructs a relatively direct, region-industry specific index for vertical linkages.

Second, this paper examines the effects of regional non-tradable sectors and immobile factors on manufacturing employment in the region. This issue is critical because some goods are non-tradable and labor is immobile even when many products are traded globally. In defining vertical linkages for each manufacturing industry, this paper includes not only other manufacturing industries, but also regional non-manufacturing industries and final demand components. This paper also considers the effects of non-tradable inputs, such as local knowledge spillovers and immobile specialized labor.

Third, to complement accumulated evidence from NAFTA and EU (e.g. Hanson (1998) and Paluzie et al. (2001)), the investigation of Japanese experiences will be required. Although Japan has not been institutionally involved in any free trade agreement, the imports began to rapidly rise after the historic yen appreciation triggered by the 1985 Plaza Accord. ${ }^{3}$ During around the same period, the geographical distribution of manufacturing becomes more dispersed in Japan. Therefore, as explained in the next section, the recent experience of Japan could be served as an example of rapidly opening/integrating economies simultaneously experiencing internal geography changes.

The rest of this paper is organized as follows. Section 2 describes changing economic geography and imports in Japan. Section 3 introduces our empirical model. Section 4 reports estimation results. Finally, Section 5 concludes.

\section{JAPAN'S ECONOMIC GEOGRAPHY AND IMPORTS}

This section describes geographical distribution of manufacturing industries in Japan, relates its

\footnotetext{
2 This difference in tradability is confirmed by Japanese Input-Output Table data and previous research on U.S. commodity flows, as will be discussed later.

${ }^{3}$ Japan has recently concluded the Economic Partnership Agreement with Singapore, but its impact on Japanese industries is quantitatively minor and should be viewed as rather symbolic.
} 
changes with import penetration, and explains our motivations for focusing on the period after 1985, especially the 1990s.

First, the manufacturing has become more evenly distributed across regions in Japan, especially during the 1990s. The cross-regional variation of manufacturing employment during 1965-2000 is shown in Figure 1. ${ }^{4}$ After a relatively stable geographical distribution in the 1980s, Japanese manufacturing has become noticeably more dispersed after around $1990 .{ }^{5}$

Second, the Japan's economic geography before 1985 seems characterized by the convergence among the three largest industrial centers. ${ }^{6}$ As a result of this convergence, these three prefectures end up with approximately equal number of manufacturing employment at $1985 .^{7}$ The major factors behind this convergence may include the urban congestion, such as rising land prices. ${ }^{8}$

After 1985, however, the three industrial centers have begun to diverge. The largest manufacturing center in Japan is now Aichi, which is famous for its home base of the world-competitive large auto manufacture Toyota and for various supporting mechanical industries. On the other hand, Tokyo shifts heavily toward service industries. ${ }^{9}$ Osaka, of which the unemployment rate is now among the highest in Japanese regions, is in a difficult adjustment from stagnant production activities. ${ }^{10}$ Thus, the trend of geographical adjustment after 1985 appears no

\footnotetext{
${ }^{4}$ Although declining concentration was also observed in the 1970s, the change in the last decade is larger $(22 \%>19 \%)$.

5 This decline of cross-regional standard deviation in the 1990s is not due to the decline of the total/average employment because the standard deviation divided by the mean also decreased. The Gini coefficient decreased in the 1990s, too.

6 These three prefectures continue to occupy one-quarter to one-third of total manufacturing employment in 47 prefectures.

7 The Japan's geography with three equally sized industrial centers differs from the Mexican experience, where Mexico City is the sole dominant industrial concentration. This difference, however, does not make Japan's geography uninteresting, since it has drastically changed and the testable implications of the theory remain applicable.

8 During this period, manufacturing employment in the other smaller prefectures, omitted from Figure 1, continued to grow until early 1990s, except only in years hit by oil shocks.

9 The employment captured by Census of Manufacturers, as shown in Figure 1, is defined by the employment in manufacturing plants, excluding headquarter offices, sales branches and research laboratories.

10 According to the recent Employment Structure Survey, the unemployment rate in Osaka is nine
} 
longer characterized solely by dispersion from urban congestion. ${ }^{11}$

Third, as is well known, Japan's imports have rapidly increased since 1985, due to the unprecedented yen appreciation triggered by Plaza Accord. ${ }^{12}$ The exchange rate change during this period is remarkable: nearly fifty percent appreciation just in one and half years (1985-86) followed by additional fifty percent appreciation in the first half of the 1990s. ${ }^{13}$ Thus, the year 1985 is viewed as the turning point for Japan both in internal geography and in international economy.

Fourth, although the yen appreciation rate was larger in 1985-90, various import changes in the 1990s are substantial and notable. Related statistics are summarized in Table I. As reported in the row (A), Japan's total imports continued to increase in the 1990s, although the growth was slightly slowed down from 1985-90 if evaluated in annual rate. However, as the row (B) demonstrates, the share of imports in total supply began to increase only after entering the 1990s.

Although the rise in aggregate import share seems mild, the structure of imports has remarkably changed in the 1990s, reflecting deeper integration of Japanese manufacturers with neighboring Asian developing countries. As shown in the rows (C) and (D) of the same table, manufactured imports from Asia and back from foreign affiliates of Japanese firms grew noticeably faster than total imports during the 1990 s, not in $1985-90 .{ }^{14}$ In contrast to increases of material/energy imports, the imports of manufactured products from overseas affiliates of Japanese firms are particularly likely to threaten traditionally tightly-knit vertical linkages among regional industries because many of these firms were formerly active within the same domestic region but

percent while the national average is five percent at September 2002.

11 The urban congestion is now less serious, as population inflows into large cities nearly ceased and land prices have dropped significantly after the burst of real estate bubble.

12 The evaluation of tariff changes in this context is difficult since protections for Japanese manufacturing industries are often provided by non-tariff measures.

13 According to the real effective exchange rate data by the Bank of Japan, the yen appreciated by 49\% (Feb.1985 to Aug.' 86 ) and 56\% (Apr.1990 to Apr.'95).

14 Manufactured imports back from Japanese foreign affiliates are predominantly from Asia ( $84 \%$ in 2000 fiscal year). 
have recently relocated their unskilled-labor intensive final assembly lines to geographically relatively close, but low-wage foreign countries. These developments undoubtedly affect incentives for geographical concentrations.

Japanese employment trend has also altered in the 1990s. As reported in the row (E) of Table I, Japanese firms have accelerated employment expansion overseas, especially in Asia during the 1990s. Although the international economy may not be a dominant determinant for the change, the total employment by manufacturing/tradable industries located in Japan has almost simultaneously declined since its peak in the early 1990s (the row (F)). ${ }^{15}$ General Japanese media also have often reported that many local economies dependent on industries competing with imports from low-wage countries or on concentration of small-sized subcontractors for final assembly manufacturers experience frequent plant shutdowns and increasing layoffs in recent years. Thus, only after entering the 1990s, the competitive impact of rising imports on domestic labor demand has become visible.

Finally, deeper import penetration appears related with more serious employment reduction in the 1990s, not in 1985-90, also at the regional level. Since region-specific data on foreign trade are not generally available, this paper constructs a measure for the import share growth GMS of each region as follows. ${ }^{16}$

$$
G M S_{r}=\sum_{j}\left[\left(\frac{L_{r j}}{L_{r}}\right) G M S_{j}\right]
$$

The subscript $r$ and $j$ index the region $(\mathrm{r}=1,2, \ldots, \mathrm{R})$ and the industry $(\mathrm{j}=1,2, \ldots, \mathrm{J})$, respectively. The employment is denoted by $L$. This region-specific index is defined based on the weighted

15 During 1985-90, employment in import-competing manufacturing industries was often easily shifted to non-tradable service industries, which expanded due to the domestic bubble boom. In the 1990s after the burst of the bubble, the rise of overall unemployment is the serious issue in Japan. 16 Inter-regional Input-Output Tables aggregate 47 prefectures only into broad nine regional blocks and figures later than 1995 are not yet available. Region-specific foreign trade data are not available for most of the prefectures in Japan. The import share is, as usual, defined by the share of imports in (shipment) + (imports) - (exports). 
average of national import share growths over industries, with industry share in each region as weights. Although import penetration may vary across regions even within the same industry, this measure can be regarded as a reasonable approximation of the intensity of import competition for individual region, given the limited availability of region-specific foreign trade data. ${ }^{17}$ The contrast between 1985-90 and 1990-2000 is summarized in Table II. As shown by comparison between high import share growth regions and low growth regions and by cross-regional correlation between import share growth and employment growth, the decline of manufacturing employment tends to be more substantial in regions with higher growth of import share in the 1990s, but clearly opposite in 1985-90. ${ }^{18}$ Thus, although we must be cautious in interpreting weak correlation without controlling for other relevant factors, the negative relation between intensified import competition and employment at the regional level is suggested for the 1990s, not for 1985-90.

As these pieces of evidence jointly indicate, the 1990s can be regarded as distinctively different from 1985-90 in terms of the relation between import penetration and regional vertical linkages. Consequently, this paper focuses on the regional/industrial variations of employment decline in the 1990s, compared with 1985-90.

\section{AN EMPIRICAL MODEL}

This section formalizes the specification and explains variables used for regressions. First, consider the profit function $\Pi$ with standard properties and differentiate it with respect to wage $w$. By Hotelling's Lemma, the labor demand is given by

17 Constructing region-specific foreign trade measures by averaging over industry values with weights given by the share of industry in each region is not new. For example, Bernard and Jensen (2000) used weighted averages to define exchange rates for individual U.S. states.

18 Besides, though omitted from the table, the cross-regional variation of import share growth becomes sizably larger in 1990-2000 than 1985-90. The import share in Table I is for the whole Japanese economy, while that in Table II is for the manufacturing. 


$$
L_{r j t}=-\partial \Pi\left(w_{r j t}, p_{j t}, z_{r j t}\right) / \partial w_{r j t}
$$

The output price is denoted by $p$. Other factors affecting the profit are captured by $z$.

To evaluate the evolving geographical concentration, we must distinguish unobserved region-specific factors, such as natural resources and resident amenity. Since these region-specific effects are not likely to change dramatically over time, we focus on the growth rates. This paper estimates the following log-linear specification. ${ }^{19}$

$$
\begin{aligned}
\Delta \ln \left(L_{r j t} / L_{j t}\right) & =\alpha+\beta_{0} \ln I N P_{r j, t-1}+\beta_{1} \ln O U T_{r j, t-1}+\gamma \ln W A G E_{r j, t-1} \\
& +\delta_{0} \ln I I A_{r j, t-1}+\delta_{1} \ln S C L_{r j, t-1}+\delta_{2} \ln D I V_{r j, t-1}+\delta_{3} \ln S I M_{r j, t-1}+\varepsilon_{r j t}
\end{aligned}
$$

The error term is expressed by $\varepsilon$. All variables are defined relative to the national average of the corresponding industry, as explained below. Taking deviations from national averages eliminates common factors in $z$ and leaves all variables region-industry specific. To avoid the simultaneity problem, all the explanatory variables are one-period lagged. Thus, this paper specifies the relative employment growth as a function of initial conditions of the region-industry relative to the national average of the industry. ${ }^{20}$

The definition of the variables is explained as follows. First, $W A G E$ is defined as relative to the industry's national wage. The negative sign is expected in the labor demand function.

$$
W A G E_{r j}=w_{r j} / w_{j}
$$

The wage variable is also supposed to partly reflect urban congestion, such as high land prices and costly commuting. ${ }^{21}$

\footnotetext{
${ }^{19}$ This type of specification is standard in analyzing changing economic geography. See Hanson (1998) and Mano and Otsuka (2000), for example.

20 Various factors in neighboring regions might also affect regional labor demand, but trades between neighboring regions are not necessarily less costly depending on road development and on real geography (e.g. high mountains). Industry-specific dummy variables, $\alpha$, partly control for trade costs. Transport costs based on road data and regional block dummies will be introduced later. 21 Although the wage should be defined after controlling for regional price differences, we skip this process due to the limit of data availability. Previous studies, including Hanson (1998), also follow
} 
Next, to capture the inter-industry linkages, we define the two indices,

$$
\begin{aligned}
& I N P_{r j}=R \sum_{h \neq j}\left(\frac{X_{j}^{h}}{X_{j}}\right)\left(\frac{Q_{r h}}{Q_{h}}\right) \\
& O U T_{r j}=R \sum_{h \neq j}\left(\frac{X_{h}^{j}}{X^{j}}\right)\left(\frac{Q_{r h}}{Q_{h}}\right)
\end{aligned}
$$

, where $X_{k}^{h}, X_{j}$ and $X^{j}$ denote the intermediate transaction from industry $h$ to industry $k$, total input supplied to industry $j$, total output from industry $j$, respectively. ${ }^{22}\left(Q_{r h} / Q_{h}\right)$ is the region $r$ 's share in industry $h$ in terms of output/shipment. Thus, these indices are weighted averages of vertically linked upstream and downstream industries within a region. ${ }^{23}$ The multiplication by $R$ (total number of regions) standardizes the average across regions as one.

Compared with the intermediate expenditure rate $\left(=\left(Q_{j}-\right.\right.$ ValueAdded $\left.\left._{j}\right) / Q_{j}\right)$, this definition excels in that rich matrix-format information from Input-Output Table is exploited. ${ }^{24}$ As far as the author knows, no previous studies have explored the relationship between domestic geography and international trade squarely through the input-output linkage, which the theory assigns the pivotal role of translating international trade into domestic geography. ${ }^{25}$

After trade liberalization, manufacturers find no longer necessary to locate themselves near other domestic manufacturers and/or consumers, and instead prefer locations far from geographical

this definition.

${ }^{22}$ This definition closely follows that by Dumais et al. (1997), but we use shipment share, instead of employment share, to avoid possible simultaneity and to be more consistent with I-O transaction values. Linkages between neighboring regions are omitted, but we will discuss road-based trade cost index and regional block dummies in the next section.

23 The effect of own industry is excluded and instead captured by the intra-industry agglomeration, defined below as (6). The reasons for this distinction will be explained there.

${ }^{24}$ Although some previous studies, such as Amiti (1999) and Paluzie et al. (2001), use it as a convenient proxy, the ratio of intermediate payment is imperfect because, for example, this ratio looks at only downstream industries. We confirmed that this proxy turned out to perform poorly in our regression exercises.

25 Ades and Glaeser (1995) bypass inter-industry linkages in their reduced-form cross-country regressions. Hanson (1998) and Paluzie et al. (2001) do not use rich information from input-output matrix in their vertical link indices. 
concentration to avoid congestion. ${ }^{26}$ In other words, industrial concentrations established previously as optimal under closed economy are likely to turn out to be excessively concentrated after trade liberalization since inexpensive imported products partly replace trades within the region. Therefore, the coefficients on these input-output linkage variables, $\beta$, must be negative if previously established concentrations are being destroyed. We can interpret this test of changing geography by the sign of $\beta$ as similar to " $\beta$-convergence" in the growth literature. ${ }^{27}$ Since we have already found preliminary evidence for " $\sigma$-convergence," i.e. declining cross-regional variation over time as reported in Figure 1 , in our case, the sign of $\beta$ is regarded as informative for investigating regional changes. ${ }^{28}$

In analyzing vertical linkages, we must distinguish backward linkage and forward linkage from the following reasons. First, since the location with rich supply of manufactured inputs is not necessarily the location proximate to large output-absorbing manufacturing industries, the distinction is critical in economic geography. Low correlation between these two indices in the real world will be confirmed later in Japanese data. Second, since the tradability of inputs may considerably differ from that of outputs, the distinction is interesting in examining the impact of international trade changes. As found by previous studies, the share of local trade tends to be higher for intermediate than final products. ${ }^{29}$ Manufactured outputs as final products are normally traded across national borders under free trade, while intermediate inputs into manufacturing, such as parts and components, are likely to be specially designed and still often purchased from suppliers with long-term relations/networks. In Japan, we actually observe the sizably higher import growth of final

26 Similar geographical dispersion is also observed when domestic trade costs decrease, but it is unlikely that new road construction significantly affects trade costs in short period like our sample period. We will add a proxy for domestic trade costs into the regression in the next section. 27 Although, as Quah (1993) pointed out, the negative $\beta$ does not necessarily mean that industries become located more evenly over time, the regression on initial conditions is a convenient specification for examining effects of various control variables.

${ }^{28}$ In addition to the cross-regional standard deviation reported in Figure 1, the standard deviation divided by the mean, and Gini coefficient of manufacturing employment also decrease in the 1990s. Besides, cross-section variance of INP and OUT slightly decreased during our sample period.

29 Wolf (1997) reports that shipment distances are shorter for intermediate than final goods, using U.S. Commodity Flow Survey data. 
demand products compared with intermediate inputs. ${ }^{30}$ If the international tradability of manufactured intermediate products increases as chains of production processes comes nearer to the final products, opening trade tends to first weaken manufacturer's linkages with output customers before linkages with input suppliers. ${ }^{31}$

This paper primarily focuses on the input-output linkages among tradables, i.e. manufacturing industries (INP (mnf), OUT (mnf)) to discuss the impact of import penetration, but we will also report comparable results for inputs from all other industries including non-manufacturing (INP (all)), and all outputs including those absorbed by non-manufacturing industries as intermediates and by final demand such as household consumption (OUT (all)).

Other geography-related variables are defined as follows. ${ }^{32}$ First, IIA is an index for intra-industry agglomeration, also known as Marshall-Arrow-Romer externalities.

$$
I I A_{r j}=\frac{L_{r j} / L_{r}}{L_{j} / L}
$$

This paper distinguishes the intra-industry agglomeration and the inter-industry linkages from the following reasons. First, as will be shown in Japanese data, the agglomeration of own sector does not necessarily coincide with the geographical concentration of related other industries. Second, the relative strength of intra-industry agglomeration compared with inter-industry linkages theoretically plays an important role in the geography model. ${ }^{33}$ Finally, the focus of this paper is to investigate

\footnotetext{
30 The share of final demand imports (total imports minus imports inputted into endogenous industry sectors in I-O Table) rose from $16 \%$ in 1985 to $38 \%$ in 1995 . No corresponding figure is available for 2000 because Input-Output Benchmark Tables have not yet published.

31 Based on U.S. commodity flows data, Hillberry and Hummels (2002) find that goods at the earlier stages of value chain tend to travel shorter distances.

32 If we can observe true real regional wage, the wage must be the sufficient statistics for geography and other geography-related variables are unnecessary. However, adjusting publicly available wage data by regional differences in prices and in product variety is practically impossible. 33 In the theory model developed by Fujita, Krugman and Venables (1999), geographical concentration of particular industry is observed when intra-industry agglomeration effect is stronger than inter-industry linkage effect.
} 
whether inter-industry linkages among regional industries, rather than agglomeration generally, are undermined during the period of increasing import penetration.

Second, $S C L$ is a proxy for the economies of scale.

$$
S C L_{r j}=\frac{L_{r j} / N_{r j}}{L_{j} / N_{j}}
$$

,where $N$ is the number of plants. This average plant size variable is intended to evaluate the region-industry differences in technology, especially in the degree of internal increasing returns.

Third, $D I V$ is an index of industrial diversity based on the squared sum of shares of all other industries.

$$
D I V_{r j}=\left[\sum_{h \neq j}\left(\frac{L_{r h}}{L_{r}}\right)^{2} / \sum_{h \neq j}\left(\frac{L_{h}}{L}\right)^{2}\right]^{-1}
$$

This index, defined as the inverse, becomes larger as the employment is more evenly distributed across industries. If the diversity of industries in a region generates positive externalities through cross-fertilization of ideas, the employment in more diversified regions must grow at higher speed. Since knowledge spillover tends to be local, this regional diversity effect is expected to survive even after trade liberalization.

Finally, following Dumais, Ellison, and Glaeser (1997), this paper introduces SIM to measure the similarity of industries located in the same region. As firms requiring similar types of workers are located near each other, workers gain due to insurance from firm-specific shocks or from ex-post appropriation of accumulated human capital, as was pointed out by Rotemberg and Saloner (2000). Firms also gain from richer pool of specific type of labor supply in the region. ${ }^{34}$ If this type of Marshallian labor pooling is significant, the employment grows faster in the regions where industries

\footnotetext{
${ }^{34}$ Although this index is intended to test the Marshallian labor pooling hypothesis, the same index could capture other industrial characteristics because industries require similar types of workers tend to share other industrial attributes.
} 
with more similar labor requirement are located. Let me index the type of occupation (e.g. professional/technical, production, and others) by $y$. The share of occupation $y$ in industry $\mathrm{j}$ 's employment is expressed by $s_{y j}$. Naturally, $\sum_{y} s_{y j}=1$ for any industry j.

$$
\operatorname{SIM}_{r j}=\left\{\sum_{y}\left[s_{y j}-\sum_{h \neq j}\left(\frac{L_{r h}}{L_{r}-L_{r j}} s_{y h}\right)\right]^{2} / \sum_{y}\left[s_{y j}-\sum_{h \neq j}\left(\frac{L_{h}}{L-L_{j}} S_{y h}\right)\right]^{2}\right\}^{-1}
$$

This index is based on a sum of squared deviations of the occupation mix of the industry and the weighted average of occupation mixes of other industries located in the same region. As in other variables, we define this index relative to the national average of the industry. By taking the inverse, this index becomes larger as more similar industries are clustered nearby. After trade liberalization, this similarity effect is expected to play a larger role since each region becomes more specialized in international division of labor while regional labor remains immobile.

To construct these indices, this paper derives region-specific industry data from Japan's Census of Manufacturers (Kogyo Tokei in Japanese). ${ }^{35}$ Detailed explanations of our data set are given in Appendix 1. The whole manufacturing is disaggregated into 21 industries at the two-digit level. ${ }^{36}$ The total number of regions (prefectures) in Japan is $47 .{ }^{37}$ Thus, we have 987 region-industry observations for each year. ${ }^{38}$ The regression results from 1990-2000 will be compared with those from 1985-90 to identify the impacts of deeper import penetration on

${ }^{35}$ Other variables that have been included in the regression are factor abundance and technology differential. We constructed proxies following previous studies, such as Amiti (1999) and Palzie et al. (2001), but found that they are statistically significant in no specifications.

36 To analyze Japan's economic geography, previous studies also use two-digit classifications. Mano and Otsuka (2000) examine five two-digit machinery industries. Dekle (2002) depends on one-digit industry classifications. Davis and Weinstein (1999) use the data of 19 two-digit industries.

37 The unit of region, prefecture (ken in Japanese), has much higher population density than U.S. states and is more like U.S. cities.

${ }^{38}$ Due to the confidentiality considerations, data for some region-industry cells are not published. For computational simplicity, we assume that figures for these cells are equal to the national average. Since these unavailable cells tend to small in size, this may overestimate the impact of these tiny prefectures/industries. However, as the number of unavailable cells is quite small, the biases by this imputation on overall estimates will be small as well. 
geographical dispersion.

The other major data source used for this paper is Input-Output Table. ${ }^{39}$ The data for SIM are drawn from Input-Output Table, of which the Employment Table disaggregates employment by occupation types. This paper combines this industry-labor requirement matrix with the region-industry employment data in Census of Manufacturers. ${ }^{40}$

The descriptive statistics are summarized in Table III. Since all the variables are defined as relative to the national average, most of the averages are around one (zero for $\Delta \ln \left(L_{r j} / L_{j}\right)$ ). Substantial cross-sectional variability is evident from the table.

The correlations between variables are shown in Table IV. Many variables at 1990 are negatively correlated with employment growth in the 1990s, but we must control for them simultaneously in the regressions. ${ }^{41}$ The noteworthy finding from this matrix is that the location proximate to large output-absorbing other manufacturing industries does not coincide with the location with rich input supply from other manufacturing industries $(\operatorname{Corr}(\operatorname{INP}(\operatorname{mnf}), O U T(m n f))=0.23)$. Consequently, in manufacturing, we must explicitly distinguish forward linkages from backward linkages. ${ }^{42}$

39 The transport equipment industry has no output purchased as intermediate inputs by other manufacturing industries. To take logarithm, we add negligible $10^{-8}$ for the output from this industry. We have also conducted regressions on the sample excluding this industry to check robustness, as will be reported in Table V.

40 The professional/technical occupations include scientific researchers and lawyers, which are normally supposed to require college degrees. On the other hand, the production occupation is roughly corresponds to the category of production workers in U.S. Census of Manufacturing. Although the employment data of more disaggregated 288 occupation types are available, the broad aggregation is appropriate for our purpose because Japanese labor market is not finely segmented by occupation types.

41 This table also confirms that multicollinearity is not serious between any variables except for alternatively defined input-output link variables.

42 Since the same table also shows that IIA is not significantly correlated with inter-industry linkages (correlation $=0.15-0.19$ ), we must distinguish the intra-industry agglomeration from inter-industry linkages. On the other hand, if we include non-manufacturing and final demand, the distinction between input link and output link is less important, as the large presence of final consumers naturally quite often implies the large input-supplying service industries in the same region $(\operatorname{Corr}(I N P(a l l), O U T(a l l))=0.90)$. This paper, however, focuses mainly on manufacturing, i.e. 


\section{ESTATIMATION RESULTS}

\subsection{Basic regression results from manufacturing industries}

The regression results from manufacturing industries are shown in Table $\mathrm{V}^{43}$ All industries are pooled with the constant term varying across industries. ${ }^{44}$ White's heteroskedasticity-consistent estimates are shown for standard errors. The difference between two sub-periods (1985-90 and 1990-2000) is statistically significant. ${ }^{45}$ Although the change before and after the burst of domestic financial bubble obviously affects many macroeconomic variables, drastic import changes in the 1990s must be a critical factor at least for changes in cross-sectional industry composition and in vertical inter-industry linkages.

First, as expected in the labor demand function, the wage is negatively related with employment growth. ${ }^{46}$ The manufacturing escaped from high-wage regions particularly during 1985-90. ${ }^{47}$ This wage effects may partly reflect other omitted factors related with urban congestion, such as high land prices in the period of real estate bubble.

Second, the output linkage variable has become clearly significantly negative in 1990-2000, while the input linkage variable is positive or insignificant. ${ }^{48}$ In other words, the employment

tradable industries, to evaluate the impact of international trade.

${ }^{43}$ To eliminate all fixed effects, the inclusion of dummies is appropriate but some variables such as $D I V$ vary little across industries within a prefecture. Adding 46 region dummies will also considerably lose degree of freedom. Hence, only industry-specific dummies are included. We will, however, include dummies for regional blocks, as used by Mano and Otsuka (2000), in the next section. See Hanson (1998) for discussions of error structures in a similar specification.

${ }_{44}$ In the Appendix 2, we allow all coefficients to vary across industries while errors in the same region may be correlated.

45 The Chow Test rejects the equality of coefficients at any conventional confidence levels.

46 In Europe, Brulhart (2001) finds that 17 out of 32 industries, especially labor-intensive cost-sensitive industries, are concentrated in peripheral (low market potential) countries rather than central (high market potential) countries.

47 The finding of insignificant wage effect in the 1990s is consistent with high unemployment rate.

48 This finding is consistent with previous results, such as Hanson (1998) and Paluzie et al. (2001).

Although she finds positive coefficient on the same variable as that by Paluzie et al. (2001), the sample period of Amiti (1999) is 1976-1989 before the completion of the EU single market. Although they find significant effect of regional demand on regional production from Japanese 
declined more during the 1990s in regions where larger output customers are present in the same region at the year 1990. This result is robust even if the transport equipment industry, whose outputs are absorbed by no other manufacturing industries, is excluded from the sample, as shown in the columns (2) and (4) of the same table. ${ }^{49}$

The inter-industry linkage is destroyed with output customers, not with input suppliers, maybe because intermediate inputs into manufacturing production such as parts and components, compared with manufactured outputs as final products, are more likely to be specially designed and difficult to purchase from arms-length trades in global spot markets. This finding is clearly consistent with the contrasting growth rates of imports of final demand products and of intermediate inputs in recent Japan. Further, the diverging evolution of manufacturing in the three industrial center regions, introduced in Figure 1, may also partly be attributable to the strong mechanical input supplier industries in Aichi, while concentration of consumers in Tokyo no longer attracts manufacturing activity. We will discuss this finding again in the next section.

Third, IIA is significantly negative, while $S C L$ seems insignificant. ${ }^{50}$ This suggests that each industry has already been excessively concentrated in Japan while internal increasing returns are no longer significant for manufacturing in the age of networking and outsourcing.

Fourth, while $D I V$ reduced growth during 1985-1990, this negative effect has disappeared or

prefecture data, Davis and Weinstein (1999) compare the home market effect with the factor abundance theory as the alternative hypothesis by using cross-section data at 1985 .

49 This weakening linkage with output-absorbing manufacturers appears not caused by general population dispersion because population mobility becomes less active in the 1990s. The congestion effects must be rather captured by the wage term. Further, manufactured input-output linkages are not correlated with urban congestions in our sample. See low correlations between INP/OUT with OUT(all) in Table III, for example.

${ }^{50}$ This finding is consistent with previous studies of Japanese data (e.g. Dekle (2002) and Mano and Otsuka (2000)). Hanson (1998) also reports that relative plant size and intra-industry agglomeration are negatively or insignificantly related with employment growth in Mexico, although significantly positive estimates have been reported for the relative plant size variable in the European cases (see Amiti (1999) and Paluzie et al. (2001)). 
weakly been reversed in the $1990 .^{51}$ We may interpret it as an indication that the cross-fertilization of ideas becomes more critical for Japanese industries in recent years. The same result is also consistent with our experience of declining regions specialized in narrow ranges of industries.

Finally, the labor pooling appears working in the 1990s, as evidenced by positive coefficient on $S I M .^{52}$ As each region becomes more specialized in deeper international division of labor, regions where industries with similar labor requirement are located close tend to grow faster.

By combining these findings, we can argue that specialized human skills, which tend to be immobile, and knowledge spillovers, which tend to be local, affect regional growth more significantly in recent years. As workers are quite immobile across regions even within a country, regions critically vary in terms of human capital accumulations and of activeness of cross-fertilization of ideas. ${ }^{53}$ As foreign trade in goods becomes more active, the geographical proximity matters less to the transportation of tradable goods, but stays important (or becomes more important) to knowledge spillovers and specialized labor supply, both of which are not the typical inputs captured by the strict definition in Input-Output Tables but clearly regarded as non-tradable inputs. Active international trade tends to decrease the importance of regional customers in selling tradable goods, but to rather emphasize regional non-tradable sectors and immobile factors.

This finding of significant roles played by regional non-tradable inputs also has deep policy implications. Our results show that manufacturers no longer find necessary to locate themselves proximate to other manufacturers, but instead prefer regions where rich non-tradable inputs are available. We can interpret it as suggesting that industrial policies targeting critical industries to promote manufacturing concentrations should, after trade liberalization, be replaced by regional

${ }^{51}$ Hanson (1998) finds that the industrial diversity has insignificant or negative estimate in a similar specification for Mexico.

${ }_{52}$ Dumais et al. (1997) also report strong effect of similarity of local industries in U.S. data.

${ }^{53}$ In spite of large variations in unemployment rates and in income levels, the inter-regional labor mobility remains low in Japan. Similar observations are reported for Europe (e.g. Fiani et al. (1997). 
economic policy enhancing human capital development and information spillovers.

\subsection{Alternative specifications}

This section checks the robustness of our principal results for the 1990s, focusing on foreign trade and tradability. First, to directly investigate the impact of import penetration on vertical linkages, this paper distinguishes industries by their growth of import share. The dummy variable for the high import share growth industries $(H I)$ is added to our regression. ${ }^{54}$ As the column (2) in Table VI shows, the coefficient on this dummy is negative if interacted with OUT, while that interacted with $I N P$ is positive and clearly insignificant, and $O U T$ not interacted with $H I$ loses its significance. ${ }^{55}$ Thus, this regression result indicates that dispersions of geographical concentrations due to weakening linkages with output absorbers is related with import penetration, although the significance is statistically weak for interactive terms. ${ }^{56}$

Second, although this paper has so far concentrated on the input-output linkages among tradables, i.e. manufacturing industries, large portions of inputs to manufacturing are supplied by service industry and some manufactured outputs are absorbed by household consumption. Consequently, this paper uses alternatively defined input-output linkage variables. The regression results are reported in the columns (3) to (4) of Table VI. While the input linkage, either defined by inputs from other manufacturing industries (INP) or inputs from all other industries including non-manufacturing (INP (all)), is found clearly insignificant, the output linkage, either defined by

54 The high import share growth industries are defined as the industries of which the import share growth is above the average. To avoid volatile fluctuations and simultaneity, the growth rate is averaged over 1985-90, 90-95, and 1995-2000, as shown in Appendix Table. Although its import share growth is slower than average, the nonferrous metal industry is included since its import share in absolute level is exceedingly higher than any other industries.

${ }^{55}$ Furthermore, as suggested by the significantly negative coefficient on $H I$ without interactions, employment decline was generally more serious in import-competing industries.

${ }^{56}$ Even if all the coefficients are allowed to vary across industries, as will be reported in Appendix 2, we confirm that the significantly negative coefficient on output linkage is found in industries with relatively high growth of import share. 
outputs purchased by other manufacturing industries (OUT) or all outputs including those absorbed by final demand and by intermediates for all manufacturing and non-manufacturing industries (OUT (all)) is significantly negative. ${ }^{57}$ The contrasting results between input link and output link, previously reported within manufacturing industries, are confirmed robust even if non-manufacturing sectors and final absorption are included.

Table VI also shows that the statistical significance and magnitude of coefficient estimates for the industrial diversity and the similarity of regional industries are substantially attenuated if non-manufacturing sectors and final demand components are included in defining input-output linkages. This contrast is rather natural, however, because the stronger presence of service industry or of consumers in the region is supposed to be associated with more active knowledge spillovers among diversified sectors or richer accumulation of specialized human capital in the region.

Finally, although we have so far assumed that trading manufactured goods is costless, transportation costs cannot be neglected even within a country. Hence, next, this paper controls for trade costs of manufacturing. ${ }^{58}$ This paper defines the trade costs $T R C$ by the following proxy.

$$
T R C_{r j}=\left\{T_{r} / \sum_{r}\left[\left(\frac{L_{r j}}{L_{j}}\right) T_{r}\right]\right\}^{-1}
$$

, where $T$ is the ratio of land used as roads in the total area of each prefecture. ${ }^{59}$ Following the weighting used in Hanson (1998), this index is region- as well as industry-specific, since the denominator is the weighted-average over regions for each industry. ${ }^{60}$ As an alternative proxy for

\footnotetext{
${ }^{57}$ We have also confirmed that our results are robust even if we define OUT by total industrial absorption (manufacturing and non-manufacturing as intermediate inputs, excluding final demand). 58 The distance to major ports/airports may be another proxy candidate for trade costs. However, locations of major ports/airports tend to coincide with industrial concentrations. Actually, in our sample, most major ports/airports are located in the prefectures nearly overlapped with the Pacific Industrial Belt in Japan.

59 Compared with total distance of roads in kilometer, the measure of land area used for roads in terms of square kilometer is better in capturing transportation capacity.

60 Hanson (1998) uses road distance from state capital to the nearest U.S. border in Mexican states.
} 
trade costs, this paper uses dummy variables for regional blocks, which aggregate 47 prefectures into nine blocks, to take account of the trade facilitating effects of geographical proximity.

The regression results including the road-based trade cost in logarithm or regional block dummies, reported in the last two columns of Table VI, confirm that previous findings are robust. Besides, the negative impact of manufacturing trade costs is found significant. ${ }^{61}$ Combined with discussions of non-tradable inputs, this result provides additional evidence for the critical role of tradability on regional manufacturing employment.

\section{CONCLUDING REMARKS}

This paper has examined changes in Japan's economic geography, focusing on vertical linkages, during the period of rising import penetration. After the historic exchange rate appreciation in 1985, Japan's imports picked up. However, only after entering the 1990s, the import share in total supply has turned to increase, with especially remarkable growth in manufactured imports back from overseas affiliates and from neighboring low-wage countries, while manufacturing has become more evenly distributed across Japanese regions in the same decade. These developments suggest the possibility that import penetration disperses concentrations by destroying regional input-output linkages. As is consistent with this interpretation, our regressions detect, for the 1990s, the significant decline of industrial concentrations, previously established proximate to output absorbers, especially in industries with high import share growths. Although other alternative explanations, such as related with the spread of information technology, have not necessarily been rejected, this finding is at least consistent with the changes in internal geography and international trade observed during this period.

61 The distinction of trade cost effect from industrial agglomeration, however, is empirically difficult because locations with low trade costs naturally attract industry concentrations. The statistical significance of output linkage decreases when trade costs are included. For regional block dummies, some of them are statistically significant, though omitted from the table to save space. 
Our regression results also indicate that non-tradable inputs, such as specialized human skills or diversified ideas accumulated and exchanged within a region, significantly affect regional growth in recent years. Since labor remains immobile across regions even within a country, and since knowledge spillover is local, the availability of these inputs considerably varies across regions. Thus, although regional transactions of tradable final products matter less to manufacturing locations, the role of geography does not diminish even after global free trade realizes.

\section{Appendix 1 Description of data}

All the data in Census of Manufacturers are downloaded from the web page of the Japan's Ministry of Economy, Trade and Industry. The employment $(L)$ is the number of employees. The wage $(w)$ is defined as the total wage payment divided by $L$. We aggregate apparel (14) and textile (15) because of the change in the industry classification during our sample period. The ordnance industry (33) is merged into the general machinery industry (29). As a result, we have 21 two-digit industries. Since the unit of region we use is the prefecture (ken in Japanese), we have data for 47 regions.

The inter-industry transaction data $(X)$ are drawn from the 90 Sector Table in Japan's Input-Output Table (1990 Input-Output Benchmark Table compiled by the Management and Coordination Agency). We aggregate I-O sectors to match two-digit industries. The non-manufacturing sectors are disaggregated into ten sectors and ten service industries, while final demand is disaggregated by Gross Prefectural Domestic Expenditure data into the following four components: private final consumption, government final consumption, private investment, and public investment.

To calculate region shares for INP and OUT, the shipment values $(Q)$, derived from Census of Manufacturers, are used for 21 manufacturing industries, while the prefecture-level data for 1990 fiscal year in Annual Report on Prefectural Accounts 2001, complied by Cabinet office, are used for nine non-manufacturing sectors (except education-research) and all four final demand components. The Gross Prefectural Domestic Product by kind of Economic Activity, defined in terms of value-added, is used for nine non-manufacturing sectors because gross output data are not available for Tokyo. For the education and research sector, region shares are calculated in terms of numbers of full-time teachers in all universities and colleges, derived from Basic Survey on School Education by the Ministry of Education and Science. The data for calculating regional shares of the ten service industries are derived from 1989 Survey of Service Industries by Census Bureau.

The industry-specific occupation type data $(s)$ are derived from Industry-Occupation Table of Employment Matrix in Input-Output Table (Appendix Table 7 in Data Report (2) of 1990 
Benchmark Table). From nine occupation types, we pick up the following two occupations: (1) professional or technical occupations (Occupation Classification Code No.1), and (2) mining/production/construction workers and apprentices (No.9), while the other seven occupation categories aggregated here as "other." In formulating SIM, we include all manufacturing industries as well as construction industry and service industry. The region-specific employment data for these non-manufacturing industries are drawn from Population Census (Kokusei Chosa in Japanese) compiled by the Statistics Bureau, the Management and Coordination Agency.

The data for roads are at April 1990, derived from 1991 Road Statistics Annual by the Ministry of Construction. All roads, including those managed by local authorities, are covered. Regional block dummy is defined by the classification in Inter-regional Input-Output Tables (Hokkaido, Tohoku, Kanto, Chubu, Kinki, Chugoku, Shikoku, Kyushu, and Okinawa).

The industry-specific foreign trade data are derived from Input-Output Table (1985, 1990 and 1995 Benchmark Tables by the Management and Coordination Agency and 2000 Updated Table by the Ministry of Economy, Trade and Industry) because foreign trade data from Custom Clearance Statistics is not compatible with domestic industry classification. Benchmark I-O Tables for 2000 have not yet been published. Since beverage, tobacco, and feed (2), and leather and fur products (24) are merged into other sectors in the 2000 Table, the growth rate averaged over 1985-1990 and 1990-1995 are used for these two industries.

\section{Appendix 2 Industry results}

The panel regressions reported in the main text constrained all the coefficients except the constant term to be equal across all industries. The impact of geography, however, is likely to differ depending on the industry. Consequently, we allow all the coefficients to vary across industries.

$$
\begin{aligned}
& \Delta \ln \left(L_{r j} / L_{j}\right)=\alpha_{j}+\beta_{0 j} \ln I N P_{r j}+\beta_{1 j} \ln O U T_{r j}+\gamma_{j} \ln W A G E_{r j} \\
& \quad+\delta_{0 j} \ln I I A_{r j}+\delta_{1 j} \ln S C L_{r j}+\delta_{2 j} \ln D I V_{r j}+\delta_{3 j} \ln S I M_{r j}+\varepsilon_{r j}
\end{aligned}
$$

Since the error terms in different equations may be correlated because the region-specific shocks affect different industries located in the same region in the same direction, we assume that

$$
\begin{aligned}
& E\left(\varepsilon_{r j} \varepsilon_{s h}\right)=\sigma_{j h} \quad \text { for } r=s \\
& \text { zero otherwise }
\end{aligned}
$$

This structure of error terms (A2) requires us to estimate 21 equations of (A1) as a system by seemingly unrelated regressions (SUR). The SUR results for 1990-2000 are summarized in Appendix Table. For $O U T$, nine out of 21 industries have negative coefficients statistically significant, while only three industries have significantly negative estimate for INP. Besides, the combination of negative $O U T$ and positive $I N P$ is observed in three industries, while the opposite 
combination is in no industry.

As import shares reported in Appendix Table indicate, the average growth rate of import shares in the nine industries with significantly negative $O U T$ is considerably higher than the import share growth averaged over all 21 industries $(37 \%>23 \%){ }^{62}$ Besides, the growth of import share is higher than average in seven out of these nine industries. Therefore, in addition to the regression result with the dummy $H I$ in the main text, these SUR estimates confirm that the vertical linkage with output absorbers is undermined particularly in industries with rapidly rising import shares.

\section{REFERENCES}

Ades, Alberto F., and Glaeser, Edward (1995), Trade and circuses: explaining urban giants, Quart. J. Econ. 110, 195-227.

Amiti, Mary (1999), Specialization patterns in Europe, Weltwirtsch. Arch./Rev. World Econ. 135, 573-593.

Bernard, Andrew, and Jensen, Bradford (2000), Understanding increasing and decreasing wage inequality. In: Feenstra, R. (Ed.), The Impact of International Trade on Wages, University of Chicago Press, Chicago, pp.227-261.

Brulhart, Marius, (2001), Evolving geographical concentration of European manufacturing industries, Weltwirtsch. Arch./Rev. World Econ. 137, 215-243.

Davis, Donald R., and Weinstein, Davis E. (1999), Economic geography and regional production structure: an empirical investigation, Europ. Econ. Rev. 43, 379-407.

Dekle, Robert (2002), Industrial concentration and regional growth: evidence from the prefectures, Rev. Econ Statist. 84, 310-315.

Dumais, Guy, Ellison, Glenn, and Glaeser, Edward L. (1997), Geographic concentration as a dynamic process, NBER Working Paper No. 6270.

Fiani, Riccardo, Gali, Giampaolo, Gennari, Pietro, and Rossi, Fulvio (1997), An empirical puzzle: falling migration and growing unemployment differentials among Italian regions, Europ. Econ. Rev. 41, 571-579.

Fujita, Masahisa, Krugman, Paul, and Venables, Anthony J. (1999), External trade and internal geography, Chapter 18 in The Spatial Economy: Cities, Regions, and International Trade, MIT Press (Cambridge, MA).

Hanson, Gordon (1998), Regional adjustment to trade liberalization, Reg. Sci. Urban. Econ. 28,

62 The import share growth of the nine industries is higher than average also between 1990 and 2000. Although the growth was low, the level of import share in the nonferrous metal industry has been extremely higher than other industries. Although both the level and growth of import share are low, the printing and publishing industry is regarded as a non-tradable service industry strongly affected by recent information technology. 
419-444.

Hillberry, Russell, and Hummels, David (2002), Explaining home bias in consumption: the role of intermediate input trade, NBER Working Paper No. 9020.

Krugman, Paul, and Livas-Elizondo, Raul (1996), Trade policy and the third world metropolis, $J$. Devel. Econ. 49, 137-150.

Mano, Yukichi, and Otsuka, Keijiro (2000), Agglomeration economies and geographical concentration of industries: a case study of manufacturing sectors in postwar Japan, $J$. Japanese Int. Economies 14, 189-203.

Paluzie, Elisenda, Pons, Jordi, and Tirado, Daniel A. (2001), Regional integration and specialization patterns in Spain, Reg. Stud. 35, 285-296.

Quah, Danny (1993), Galton's fallacy and tests of the convergence hypothesis, Scand. J. Econ. 95, 427-443.

Rotemberg, Julio, and Saloner, Garth (2000), Competition and human capital accumulation: a theory of interregional specialization and trade, Reg. Sci. Urban. Econ. 30, 373-404.

Wolf, Holger (1997), Patterns of intra- and inter-state trade, NBER Working Paper No.5939. 
TABLE I

CHANGES IN JAPAN'S IMPORTS AND RELATED STATISTICS

\begin{tabular}{|r|c|c|c|}
\hline YEAR & 1985 & 1990 & 2000 \\
\hline (A) Total imports & 31.08 & 33.86 & 40.94 \\
\hline (B) Import share & 5.63 & 5.26 & 5.82 \\
\hline $\begin{array}{r}\text { (C) Manufactured imports from Asia } \\
\text { (\% share in total manufactured imports) }\end{array}$ & 21.32 & 26.27 & 48.88 \\
\hline $\begin{array}{r}\text { (D) Manufactured imports back from overseas } \\
\text { affiliates of Japanese firms (\% share in total imports) }\end{array}$ & $4.5^{*}$ & 4.2 & 14.8 \\
\hline $\begin{array}{r}\text { (E) Employment by Japanese affiliates in Asia } \\
\text { (Thousand people) }\end{array}$ & 529 & 676 & 2038 \\
\hline (F) Manufacturing employment in Japan & & 11.17 & 9.18 \\
\hline
\end{tabular}

Source: (A) and (C) from Foreign Trade Statistics, (B) from Input-Output Tables, (D) and (E) from Ministry of Economy, Trade and Industry's Survey of Overseas Business Activities (April-March, 1986 figure in *), and (F) from Census of Manufacturers. 
TABLE II

CROSS-REGIONAL EMPLOYMENT VARIATIONS AND IMPORT SHARE

\begin{tabular}{|c|c|c|}
\hline & $1985-1990$ & $1990-2000$ \\
\hline Average over all regions & 5.04 & -15.5 \\
\hline in the highest $G M S$ region & 6.94 & -16.5 \\
\hline in the lowest $G M S$ region & 1.74 & 0.639 \\
\hline in the upper $10 \%$ GMS regions & 3.30 & -17.0 \\
\hline in the lower $10 \% G M S$ regions & -1.13 & -15.0 \\
\hline Cross-regional correlation between & & \\
\hline$G M S$ and $L$ growth & 0.175 & -0.042 \\
\hline
\end{tabular}

Notes: $G M S$ and $L$ denote import share growth and employment, respectively. Growth rates are in percentages between 1985 and 1990, or between 1990 and 2000. The upper/lower 10\% rows report the average over top/bottom five prefectures in the GMS ordering of all 47 prefectures. The industry import share data are from Input-Output Tables, while regional employment data are from Census of Manufacturers. See (1) for the definition of region-specific GMS. 
TABLE III

SUMMARY STATISTICS

\begin{tabular}{|c|c|c|c|c|}
\hline & Average & St. Dev. & Max & Min \\
\hline$\Delta \ln \left(L_{r j} / L_{j}\right)$ & 0.076 & 0.257 & 2.103 & -1.324 \\
\hline$I N P(m n f)$ & 1.000 & 1.101 & 6.431 & 0.016 \\
\hline$I N P($ all $)$ & 1.000 & 1.230 & 9.792 & 0.068 \\
\hline OUT (mnf) & 1.000 & 1.232 & 10.570 & 0.006 \\
\hline OUT (all) & 1.000 & 1.237 & 12.203 & 0.088 \\
\hline$I I A$ & 1.016 & 0.836 & 10.987 & 0.027 \\
\hline$S C L$ & 1.114 & 0.611 & 6.063 & 0.140 \\
\hline DIV & 0.770 & 0.195 & 2.105 & 0.364 \\
\hline$S I M$ & 1.165 & 1.106 & 29.685 & 0.040 \\
\hline$W A G E$ & 0.892 & 0.183 & 1.570 & 0.056 \\
\hline
\end{tabular}

(Notes)

1. "Average," "St. Dev.," "Max," and "Min" are the unweighted average, standard deviation, maximum and minimum among all industries/prefectures. All variables are defined as relative to the national average of the industry. See text for abbreviations.

2. All the values except $\Delta \ln \left(L_{r j} / L_{j}\right)$ are those at 1990 , while $\Delta \ln \left(L_{r j} / L_{j}\right)$ is the $\log$ difference between 1990 and 2000. 
TABLE IV

CORRELATION BETWEEN VARIABLES

\begin{tabular}{|c|c|c|c|c|c|c|c|c|c|c|}
\hline & L & Wage & $\begin{array}{c}\text { INP } \\
\text { (mnf) }\end{array}$ & $\begin{array}{c}\text { INP } \\
\text { (all) }\end{array}$ & $\begin{array}{c}\text { OUT } \\
\text { (mnf) }\end{array}$ & $\begin{array}{c}\text { OUT } \\
\text { (all) }\end{array}$ & IIA & SCL & DIV & SIM \\
\hline L & 1 & & & & & & & & & \\
\hline Wage & -0.28 & 1 & & & & & & & & \\
\hline INP (mnf) & -0.23 & 0.53 & 1 & & & & & & & \\
\hline INP (all) & -0.25 & 0.47 & 0.87 & 1 & & & & & & \\
\hline OUT (mnf) & -0.07 & 0.20 & 0.23 & 0.24 & 1 & & & & & \\
\hline OUT (all) & -0.25 & 0.51 & 0.82 & 0.90 & 0.23 & 1 & & & & \\
\hline IIA & -0.43 & 0.38 & 0.19 & 0.19 & 0.19 & 0.15 & 1 & & & \\
\hline SCL & -0.23 & 0.33 & 0.14 & 0.04 & 0.16 & 0.03 & 0.51 & 1 & & \\
\hline DIV & -0.17 & 0.31 & 0.48 & 0.37 & 0.12 & 0.29 & 0.35 & 0.15 & 1 & \\
\hline SIM & 0.04 & 0.04 & 0.10 & -0.03 & 0.02 & -0.00 & 0.00 & 0.03 & 0.00 & 1 \\
\hline
\end{tabular}

(Notes)

1. All variables are in logarithm form, while " $L$ " in this table denotes the relative employment growth $[\Delta \ln (L(r, j) / L(j))]$. See text for other abbreviations.

2. All the variables except " $L$ " are those at 1990 , while " $L$ " is the growth between 1990 and 2000. Shown is the correlation for each variable across all regions/industries combined. 
TABLE V

BASIC REGRESSION RESULTS

\begin{tabular}{|c|c|c|c|c|}
\hline Variables & $(1)$ & $(2)$ & $(3)$ & $(4)$ \\
& $1985-90$ & $1985-90$ & $1990-2000$ & $1990-2000$ \\
\hline INP & 0.0274 & 0.0167 & -0.0104 & -0.0131 \\
& $(0.0120)$ & $(0.0117)$ & $(0.0123)$ & $(0.0124)$ \\
\hline OUT & -0.0234 & -0.0149 & -0.0295 & -0.0284 \\
& $(0.0132)$ & $(0.0135)$ & $(0.0129)$ & $(0.0132)$ \\
\hline$W A G E$ & -0.2459 & -0.2348 & -0.0647 & -0.0741 \\
& $(0.0639)$ & $(0.0663)$ & $(0.0690)$ & $(0.0734)$ \\
\hline$I I A$ & -0.0556 & -0.0575 & -0.1175 & -0.1150 \\
& $(0.0144)$ & $(0.0146)$ & $(0.0167)$ & $(0.0169)$ \\
\hline$S C L$ & 0.0193 & 0.0083 & 0.0023 & 0.0004 \\
& $(0.0268)$ & $(0.0276)$ & $(0.0225)$ & $(0.0228)$ \\
\hline$D I V$ & -0.0778 & -0.0589 & 0.0582 & 0.0583 \\
& $(0.0288)$ & $(0.0288)$ & $(0.0345)$ & $(0.0354)$ \\
\hline$S I M$ & 0.0011 & -0.0026 & 0.0277 & 0.0278 \\
& $(0.0094)$ & $(0.0095)$ & $(0.0138)$ & $(0.0142)$ \\
\hline$R^{2}$ & 0.1738 & 0.1759 & 0.2670 & 0.2709 \\
\hline
\end{tabular}

(Notes) The dependent variable is the region-industry employment growth rate relative to the national average of the industry. Industry-specific fixed effect dummy variables are included. Hetroskedasticity-consistent standard errors are in parentheses. The columns (2) and (4) are results from the sample excluding the transport equipment industry. 
TABLE VI

ALTERNATIVE SPECIFICATIONS

\begin{tabular}{|c|c|c|c|c|c|c|}
\hline & $(1)$ & $(2)$ & $(3)$ & $(4)$ & $(5)$ & $(6)$ \\
\hline INP & -0.0104 & -0.0206 & -0.0008 & ------- & -0.0016 & -0.0168 \\
& $(0.0123)$ & $(0.0175)$ & $(0.0140)$ & & $(0.0125)$ & $(0.0127)$ \\
\hline INP (all) & ------- & ------- & ------- & -0.0144 & ------- & ------- \\
& & & & $(0.0212)$ & & \\
\hline OUT & -0.0295 & -0.0048 & ------- & ------- & -0.0186 & -0.0400 \\
& $(0.0129)$ & $(0.0169)$ & & & $(0.0126)$ & $(0.0145)$ \\
\hline OUT (all) & ------- & ------- & -0.0505 & -0.0381 & ------- & ------- \\
& & & $(0.0172)$ & $(0.0242)$ & & \\
\hline WAGE & -0.0647 & -0.0554 & -0.0587 & -0.0599 & -0.0362 & -0.0456 \\
& $(0.0690)$ & $(0.0696)$ & $(0.0677)$ & $(0.0657)$ & $(0.0659)$ & $(0.0678)$ \\
\hline IIA & -0.1175 & -0.1169 & -0.1150 & -0.1145 & -0.1205 & -0.1211 \\
& $(0.0167)$ & $(0.0165)$ & $(0.0165)$ & $(0.0166)$ & $(0.0168)$ & $(0.0169)$ \\
\hline SCL & 0.0023 & -0.0023 & -0.0036 & -0.0039 & -0.0052 & 0.0015 \\
& $(0.0225)$ & $(0.0228)$ & $(0.0233)$ & $(0.0226)$ & $(0.0224)$ & $(0.0248)$ \\
\hline DIV & 0.0582 & 0.0546 & 0.0394 & 0.0439 & 0.0731 & 0.1151 \\
& $(0.0345)$ & $(0.0343)$ & $(0.0343)$ & $(0.0343)$ & $(0.0352)$ & $(0.0401)$ \\
\hline SIM & 0.0277 & 0.0284 & 0.0149 & 0.0142 & 0.0190 & 0.0271 \\
& $(0.0138)$ & 0.0137 & $(0.0140)$ & $(0.0139)$ & $(0.0135)$ & $(0.0140)$ \\
\hline$H I^{*} I N P$ & ------- & 0.0141 & ------- & ------- & ------- & ------- \\
& & $(0.0211)$ & & & & \\
\hline$H I^{*}$ OUT & -------- & -0.0347 & ------- & ------- & ------- & ------- \\
& & $(0.0228)$ & & & & \\
\hline$H I$ & -------- & -0.7489 & ------- & ------- & ------- & ------- \\
& & $(0.3023)$ & & & & \\
\hline TRC & -------- & ------- & ------- & ------- & -0.0692 & ------- \\
& & & & & $(0.0179)$ & \\
\hline$R^{2}$ & 0.2670 & 0.2690 & 0.2708 & 0.2712 & 0.2777 & 0.2881 \\
\hline
\end{tabular}

(Notes) The sample period is 1990-2000. The column (1) is reproduced from (3) in Table V for comparison. The column (6) includes dummies for regional blocks. Industry dummies are included in all cases. 
Figure 1 Japan's regional employment 1965-2000

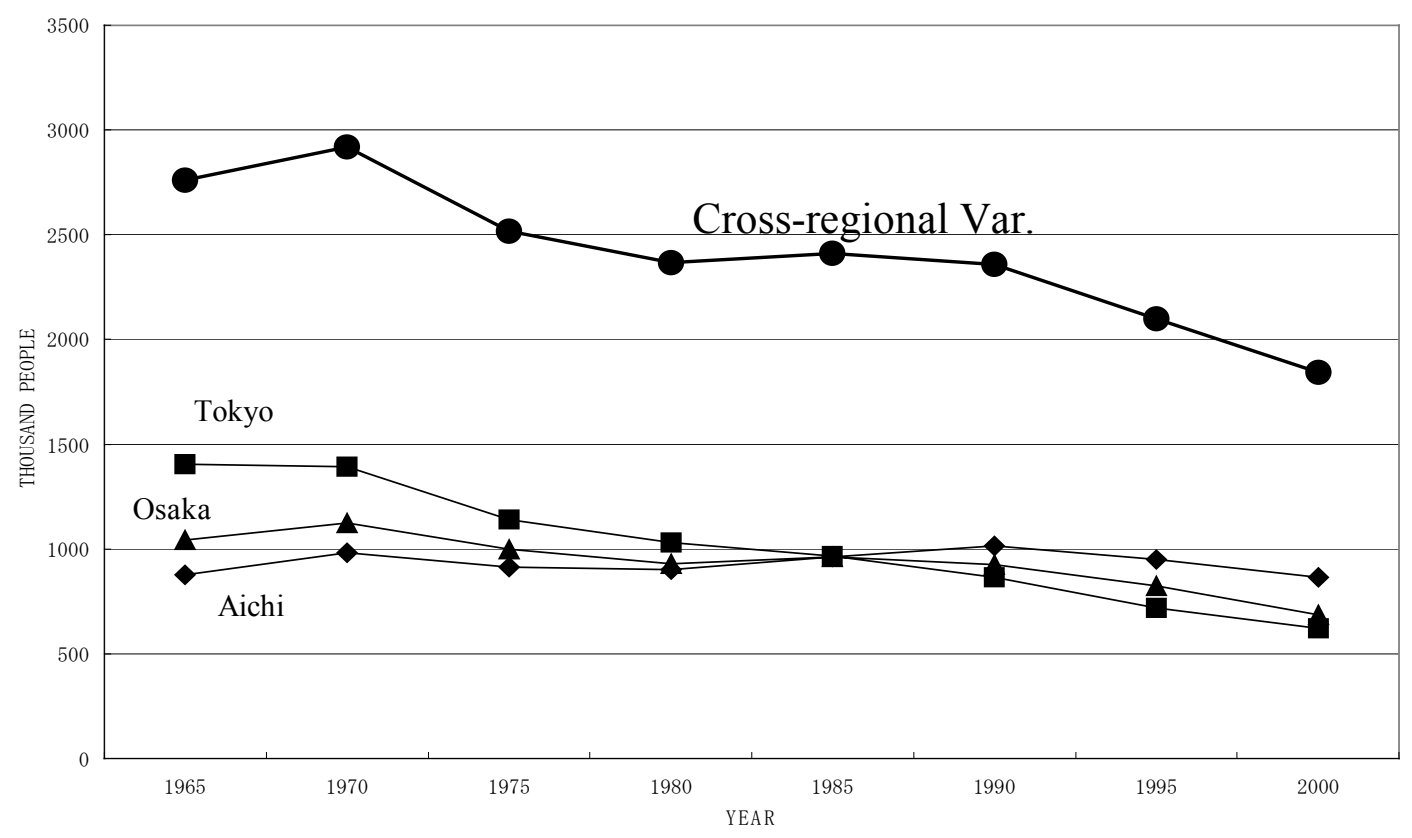

(Notes) The manufacturing employment of the three largest prefectures is measured in thousand people. The cross-regional variation (the standard deviation across all 47 prefectures) is shown after multiplied by ten. 
Appendix TABLE

INDUSTRY SUR RESULTS AND IMPORT SHARE

\begin{tabular}{|c|c|c|c|c|c|c|c|c|c|c|}
\hline & INP & OUT & $W$ & IIA & $S C L$ & $D I V$ & SIM & $\mathrm{R}^{2}$ & MS & GMS \\
\hline Food mnf. & $(-)$ & & $(+)$ & & & & & .18 & 7.1 & 20.6 \\
\hline Bvrg./tobacco/feed & $(+)$ & $(-)$ & & & $(-)$ & & $(-)$ & .27 & 3.6 & 56.2 \\
\hline Apparel \& Textile & & $(-)$ & & & & & & .16 & 8.5 & 58.3 \\
\hline Timb/Wood prod. & & & $(-)$ & $(+)$ & $(-)$ & & $(+)$ & .47 & 10.6 & 32.9 \\
\hline Furniture \& fixture & $(+)$ & $(-)$ & & $(-)$ & $(+)$ & & & .40 & 2.7 & 65.7 \\
\hline Pulp \& Paper prod. & & & & $(-)$ & & $(+)$ & $(+)$ & .11 & 4.3 & 7.1 \\
\hline Print/Publishing & & $(-)$ & & & & & $(-)$ & .19 & 0.6 & 1.5 \\
\hline Chemical products & $(+)$ & & $(-)$ & $(-)$ & $(+)$ & $(+)$ & $(+)$ & .45 & 8.0 & 12.7 \\
\hline Petro/coal products & $(-)$ & & & $(-)$ & $(+)$ & & & .53 & 13.0 & 2.0 \\
\hline Plastic products & & $(-)$ & & $(-)$ & & $(+)$ & $(+)$ & .59 & 1.0 & 54.3 \\
\hline Rubber products & & & & $(-)$ & $(+)$ & & $(+)$ & .17 & 5.3 & 37.8 \\
\hline Leather \& Fur prod. & & $(+)$ & & & & $(-)$ & & .15 & 13.1 & 79.0 \\
\hline Ceramic/stone/clay & & $(-)$ & & $(-)$ & & & & .27 & 2.4 & 30.0 \\
\hline Iron \& Steel & & & & & $(+)$ & & $(+)$ & .23 & 1.9 & 12.8 \\
\hline Nonferrous Metals & $(+)$ & $(-)$ & $(+)$ & $(-)$ & & & & .49 & 25.2 & 2.8 \\
\hline Metal products & & $(-)$ & & $(-)$ & $(+)$ & & & .41 & 1.1 & 33.5 \\
\hline General Machinery & & & $(-)$ & $(-)$ & $(+)$ & & & .57 & 3.0 & 35.0 \\
\hline Electric Machinery & $(-)$ & & & $(-)$ & $(+)$ & $(+)$ & & .70 & 4.3 & 62.5 \\
\hline Transport equipmt. & & & $(-)$ & & $(+)$ & & & .31 & 2.9 & 29.3 \\
\hline Precision instrmt. & & $(-)$ & $(+)$ & & & $(+)$ & & .50 & 11.8 & 34.5 \\
\hline Miscellaneous mnf. & & & & $(-)$ & $(+)$ & & & .24 & 12.9 & 33.0 \\
\hline
\end{tabular}

(Notes) Shown are the sign of coefficients estimated for 1990-2000 by Seemingly Unrelated Regression (SUR), significant at the 5\% significance level. The import share (MS) is in percentage at 1985. The growth rate of import share (GMS) is the average over percentage growths in 1985-90, 1990-95, and 1995-2000. 